\title{
Chemical evaluation and anti-radical activity of varieties of Morus alba l. (morera, moraceae) from Venezuela
}

Daynet Sosa del Castillo1,2, José Johnatan Quintero Mesa ${ }^{3}$, Yeifre José Rojas Alvear³, María Rodríguez ${ }^{3}$, Ramón Antonio Rea Suárez² y Migdalia Miranda Martínez ${ }^{1}$

DOl. 10.21931/RB/2021.06.01.21

Abstract: Mulberry (Morus alba L.), known as white mulberry, is a plant widely used in medicine and food due to its chemical composition. The qualitative study of the primary and secondary metabolites of the methanolic extracts of the four varieties of Morera was developed by chromatographic profile (TLC) against standards. Quantification was performed through colorimetric assays. All results were analyzed through statistical analysis. The results indicated the existence of similarities between varieties for both primary and secondary metabolites. The radical capacity of the varieties analyzed was also evaluated by finding that the Táchira variety had the highest anti-radical capacity with an IC50 of $553.58 \pm 3.23 \mu \mathrm{g} / \mathrm{mL}$ followed by the Maracay IC50 varieties of $1054.01 \pm 1.76 \mu \mathrm{g} / \mathrm{mL}$, Boconó IC50 of $1398.93 \pm 2.23 \mu \mathrm{g} / \mathrm{mL}$ and Yu-62 IC50 of $3817.89 \pm 18.08 \mu \mathrm{g} / \mathrm{mL}$.

It was found that the use of the thin layer chromatography (CCF) technique was efficient to detect the presence of phenolic compounds, soluble carbohydrates, and amino acids in the four varieties studied. The Yu-62 variety had the highest total phenol contents and proteins; the amino acid content was higher for the Táchira variety, while the soluble carbohydrate content was higher in the Boconó variety. The presence of saponins was not detected in any of the four varieties evaluated.

Key words: Antiradical ability, Mulberry, primary metabolites, secondary metabolites, qualitative profile, quantification, varieties.

\section{Introduction}

The mulberry is a shrub with shiny-light green leaves, prominent whitish veins on the underside, and an asymmetric base $^{1}$; purple, white, black, or pink fruits with a length of $5 \mathrm{~cm}^{2}$.

It is native to Asian countries, used in sericulture, and introduced to other continents, which has led to the creation and extension of a large number of varieties with excellent biomass production, nutritional quality, and high resistance to attack by pests and diseases in a wide range of climate and soil conditions ${ }^{3}$.

For the genus, Morus a total of 24 species are reported 4 , the best-known being $M$. alba, $M$ nigra, $M$ indica, $M$ laevigata and $M$ bombycis, which are distributed all over the world, from temperate areas (altitude: 4000 masl ) to tropical (dry and humid) $)^{5}$ grouped into five regions 6 : East Asia, Archipelago of Malaysia, Southwest Asia, North, Central, and South America and West Africa.

According to Chan et al. ${ }^{7}$, mulberry foliage is the leading food of silkworms; Its leaves are used as food for livestock and its fruits as food products.

Flavonoids and phenolic compounds, in general, are the main components of the plant in its various organs, also mentioning alkaloids, amino acids, and fatty acids, among others. Various biological activities are reported for the species' leaves, including antioxidants, antimicrobial, skin whitening, cytotoxic, antidiabetic, glycosidase inhibition anti-hyperlipidaemias, anti-atherosclerotic, anti-obesity, cardioprotective, and enhancement cognitive ${ }^{7-12}$. Fruits are rich in anthocyanins and alkaloids with antioxidant, antidiabetic, antiatherosclerosis, anti-obesity, and hepatoprotective activities ${ }^{13,14}$. The root's bark contains flavonoids, alkaloids, and stilbenes, with antimicrobial, skin whitening, cytotoxic, anti-inflammatory anti-hyperlipidaemic properties ${ }^{15}$. Other pharmacological properties of M. alba include antiplatelet, anxiolytic, antiasthmatic, anthelmintic, antidepressant, cardioprotective, and immunomodulatory activities. The phytochemistry and pharmacology of the different parts of the mulberry tree confirm its traditional and current uses as forage, food, cosmetics, and medicine, the species being a plant with promising medicinal properties ${ }^{7}$. This work's objective was to study comparatively the chemical composition and root activity of the leaves of four varieties of Morus alba cultivated in Venezuela.

\section{Methods}

\section{Collection and treatment}

The Morus alba varieties studied were collected in the greenhouse of the Institute for Advanced Studies (IDEA), located at an altitude of 1179 meters above sea level, 10 ${ }^{\circ}$ 25'59" $\mathrm{N}, 66^{\circ} 52^{\prime} 59^{\prime \prime} \mathrm{W}$, in the Baruta municipality, Miranda state of the Metropolitan District of Caracas, where they are identified as Maracay (Ma 001), Táchira (Ta 002), Boconó (Bo 003) and Yu-62 (Yu 004).

The varieties used were collected from plants with a height of no more than $50 \mathrm{~cm}$ in height and little biomass, with leaves of approximately $8 \mathrm{~cm}$ long.

Two procedures were carried out: In the first, samples of 10 leaves of each plant per variety (three plants) were taken, and they were dried in the open air for one week, then crushed and macerated in methanol for the preparation of the corresponding extract. In the second procedure, 10 leaves were taken from each plant (total 30); they were cleaned with water and alcohol for transfer to the laboratory in a cellar with liquid nitrogen. The leaves were macerated with liquid nitrogen and stored in a refrigerator at a temperature of $-80^{\circ} \mathrm{C}$ for later use.

\footnotetext{
${ }^{1}$ Escuela Superior Politécnica del Litoral, ESPOL, Facultad de Ciencias de la Vida, Centro de Investigaciones Biotecnológicas del Ecuador, Guayaquil, Ecuador

2 Área de Agricultura y Soberanía Alimentaria, IDEA, Instituto de Estudios Avanzados, Caracas, Venezuela.

${ }^{3}$ Escuela de Química, Facultad de Ciencias, Universidad Central de Venezuela, Caracas, Venezuela. 


\section{Extraction and analysis of varieties}

Protein extraction: $100 \mathrm{mg}$ of the sample placed in Eppendorf tubes were added $1 \mathrm{~mL}$ of buffer constituted by Tris- $\mathrm{HCl}$, urea, EDTA disodium salt, tween 20 , sodium diacid phosphate and $B$ mercapto-ethanol. It was stirred to homogenize; it was centrifuged at 10,000 rpm for 10 min separating the solid (soluble proteins).

\section{Extraction of carbohydrates and amino acids (as free proline)}

$100 \mathrm{mg}$ of the sample placed in Eppendorf tubes were added $1 \mathrm{~mL}$ of $80 \%$ ethanol; It was stirred until homogenized, it was centrifuged at $4000 \mathrm{rpm}$ for 8 min evaporated in the hood at room temperature until obtaining $1 \mathrm{~mL}$ aqueous phase: carbohydrates and amino acids. The process was repeated twice.

\section{Extraction of Phenols (soluble and bound to the cell wall)}

$100 \mathrm{mg}$ of the sample placed in Eppendorf tubes, $500 \mu \mathrm{L}$ of methanol were added, it was stirred until homogenized, it was centrifuged at $12000 \mathrm{rpm}$ for $15 \mathrm{~min}$. The supernatant contained soluble phenols. $250 \mu \mathrm{L}$ of $2 \mathrm{M} \mathrm{NaOH}$ was added to the solid residue, it was stirred until homogenized, incubated at $70{ }^{\circ} \mathrm{C}$ for 16 hours, neutralized with $250 \mu \mathrm{L}$ of $2 \mathrm{M} \mathrm{HCl}$, centrifuged, and the supernatant consisted of phenolic compounds bound to the cell wall.

\section{Qualitative analysis of the varieties}

TLC performed methanolic extracts, and the solvent systems and standards used were the following:

\section{Quantification of primary and secondary metabolites}

\section{Proteins}

A $100 \mu \mathrm{L}$ aliquot was taken from the initial extraction and initially diluted to a volume of $10 \mathrm{~mL}$ with water. $\mathrm{A} 1 \mathrm{~mL}$ aliquot was taken, and then $1 \mathrm{~mL}$ of Bradford's reagent (Coomassie blue in sulfuric acid) was added and stirred until homogenized. It could settle. As a standard, bovine serum albumin solutions of different concentrations were prepared, and the same treatment as the sample was applied. Spectrophotometric analysis was performed for quantification using the Bradford method ${ }^{17}$. The values of the samples were obtained from the corresponding calibration curve. The results were expressed as $\mathrm{mg} / \mathrm{g}$ of fresh mass equivalent to bovine serum albumin.

\section{Total carbohydrates}

A $100 \mu \mathrm{L}$ aliquot of the sample from the extraction was taken and diluted with distilled water to $1 \mathrm{~mL}$. $0.5 \mathrm{~mL}$ of a $5 \%$ phenol solution and carefully $2.5 \mathrm{~mL}$ of concentrated sulfuric acid were added. It was stirred until homogeneous and allowed to stand for $30 \mathrm{~min}$. Different concentrations of glucose solutions were prepared as a standard, and the same treatment as the sample was applied. The Dubois method ${ }^{18}$ carried out quantification. The maximum wavelength of absorption was $492 \mathrm{~nm}$. The values of the samples were obtained from the calibration curve. The results were expressed in $\mathrm{mg} / \mathrm{g}$ of fresh mass equivalent to glucose.

\section{Soluble phenols bound to the cell wall (total phenols)}

$100 \mu \mathrm{L}$ of the plant extract was taken and diluted with $1 \mathrm{~mL}$ with distilled water. Subsequently, $100 \mu \mathrm{L}$ of the Folin-Ciocalteau reagent was added, and it was left to stand for 5 min. $600 \mu \mathrm{L}$ of $1 \mathrm{M} \mathrm{NaOH}$ saturated with $\mathrm{Na} 2 \mathrm{CO} 3$ was im-

\begin{tabular}{|l|l|l|}
\hline Metabolites & Standards & Solvent/developer system \\
\hline Amino acids & $\begin{array}{l}\text { L-proline, } \\
\text { L-arginine }\end{array}$ & $\begin{array}{l}\text { n-butanol: acetone: glacial acetic acid: water (35: } \\
\text { 35: 10: 20), developer 2\% ninhydrin in ethanol. }\end{array}$ \\
\hline Carbohydrates & $\begin{array}{l}\text { Sucrose, } \\
\text { glucose }\end{array}$ & $\begin{array}{l}\text { 2-propanol-butanol-water (12: 3: 4), developer } \\
\text { Naphthol in acid }\end{array}$ \\
\hline Flavonoids & Routine. & $\begin{array}{l}\text { Ethyl acetate-formic acid-glacial acetic acid-water } \\
(100: 11: 11: 10), \text { UV developer } 254 \text { and 365nm }\end{array}$ \\
\hline
\end{tabular}

\section{Amino acids, such as free proline}

A $20 \mu \mathrm{L}$ aliquot of the plant extract was taken and diluted to a volume of $0.5 \mathrm{~mL}$ with distilled water. This was mixed with $0.5 \mathrm{~mL}$ of ninhydrin and $0.5 \mathrm{~mL}$ of acetic acid. It was stirred to homogenize and subsequently placed in a water bath at $100^{\circ}$ $\mathrm{C}$ for 1 h. It could cool. $2 \mathrm{~mL}$ of toluene was added, and it was stirred vigorously. L-proline solutions of different concentrations were prepared and the same treatment as the sample was applied as a standard. For quantification, a colorimetric method was used using ninhydrin as a reagent. The maximum absorption length was $520 \mathrm{~nm}^{16}$. The values of the samples were obtained from the corresponding calibration curve. The results were expressed in $\mathrm{mg} / \mathrm{g}$ of fresh mass equivalent to L-proline. mediately added and left to incubate at room temperature for 1h. Chlorogenic acid solutions of different concentrations were prepared as a standard. The same treatment as the sample was applied. Quantification was carried out by the Folin -Cioucalteu spectrophotometric method ${ }^{19,20}$. The values of the samples were obtained from the corresponding calibration curve. The results were expressed in $\mathrm{mg} / \mathrm{g}$ of fresh mass equivalent to chlorogenic acid.

\section{Routine determination by HPTLC method}

Once the thin layer chromatography was developed applying the conditions required for the analyzed sample and varying the concentration of the standard, maintaining a seeding volume of $3 \mu \mathrm{L}$ in each case, a photo was taken of each plate at a wavelength of $254 \mathrm{~nm}$ using a UV radiation lamp and maintaining the same focal distance for each of them. Said photo 
was subjected to an executable program in MATLAB supplied by the laser laboratory of the School of Chemistry of the UCV Faculty of Sciences for the construction of the corresponding calibration curve.

\section{Statistical analysis}

Analysis of variance and test of means were performed on all the variables under study, applying the Di Rienzo, Guzmán, and Casanova's test (DGC). For this, the statistical program InfoStat 2013 (Di Rienzo et al.) ${ }^{21}$.

\section{Results}

\section{Qualitative analysis. Visualization of the chemical profile of the varieties}

Figure 1 shows the chromatographic profiles of the different primary and secondary metabolites evaluated: amino acids, carbohydrates, and flavonoids, indicating the solvent systems, developers, and standards used.

\section{Quantification of free L-proline and proteins}

Table 1 shows the results for the concentration of amino acids expressed as L-proline and proteins for the three replicates analyzed in the four varieties studied and the statistical analysis results.

\section{Quantification of soluble carbohydrates and phenols}

The quantification of soluble carbohydrates and total phenols is described in table 2, where the results of the statistical analysis are also expressed.

\section{Routine quantification by HTLC in the Morus alba varieties: Maracay and Boconó and anti-radical activity}

Table 3 shows the results of the routine quantification in the varieties that chromatographically gave positive results for this flavonoid, in addition to the determination of the anti-radical activity with DPPH, for the evaluation of the antioxidant activity of the extracts of the varieties under study also indicates the results of the statistical analysis.
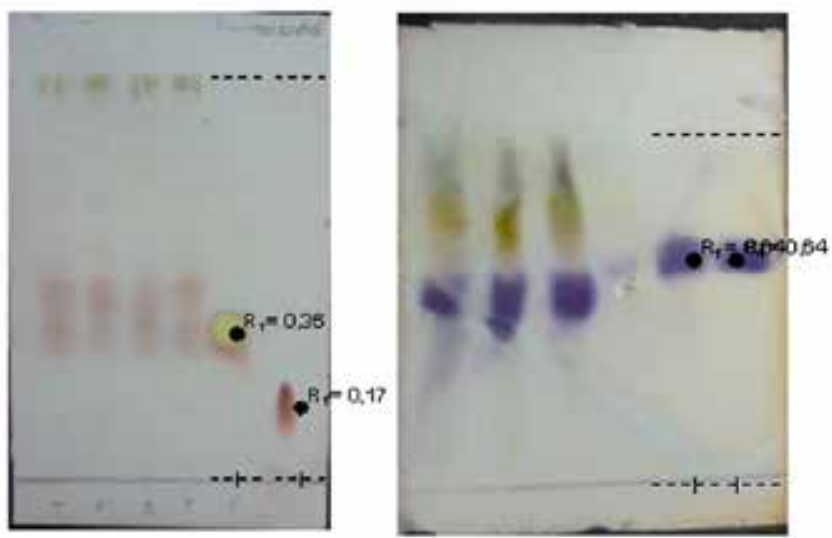

\section{Discussion}

\section{Qualitative analysis. Visualization of the chemical profile}

The primary and secondary metabolites (amino acids, carbohydrates, proteins, and phenolic compounds) produce benefits to other living organisms that feed on the plants that contain them, facilitating their growth and development. In some studies, it has been shown that feeding different animals with mulberry leaves produces an increase in the meat's quality and other characteristics of the animals ${ }^{22-24}$

Of the 20 essential amino acids present in mulberry leaves, the concentration levels of Proline, Glutamine, Glycine, and Valine ${ }^{25}$ are considerable. It is possible to observe on the chromatographic plate (fig 1-I) a series of purple-violet spots associated with these compounds and a yellow-orange spot of Rf 0.36 corresponding to L-proline. Additionally, the arginine pattern Rf 0.17 could be observed. By comparing the chromatographic profile of the four varieties studied with the L-proline standard, this amino acid's presence could be detected, with different intensities, in all the samples studied. Concerning carbohydrates, a very complex composition of monosaccharides and polysaccharides is proposed, highlighting the concentrations of glucose and sucrose ${ }^{26}$; The qualitative analysis of the varieties Táchira, Maracay, Boconó and Yu-62, (fig 1-II), compared with the sucrose and glucose standards, showed spots coinciding with the standards, which shows their presence.

In the phenolic compounds for the chromatographic analysis, analysis conditions were used that allowed the detection of both flavonoids and glycosides thereof, considering previous reports of the detection of these metabolites in the species $^{27-29}$. Figure 1-III shows the chromatographic profile of the different varieties studied and their comparison with the routine pattern, which appears as an orange spot under 365 nm UV light (Rf: 0.31), in two of the four varieties studied. For the Boconó and Yu-62 varieties, this flavonoid's presence was not detected; however, in the chromatographic profile, another spot with a possible flavonol nucleus appears with an Rf of 0.91, which was detected in all the varieties studied and which

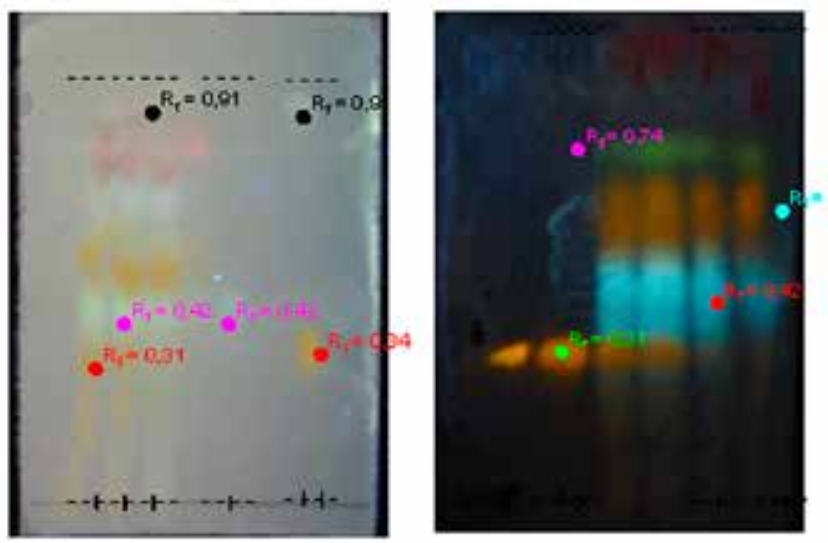

Figure 1. Chromatographic profile of the different metabolites detected in the four varieties under study.

I. Amino acids. (Táchira (T), Maracay (M), Boconó (B), Yu-62 (Y)) and control substance (L-proline (P), L-arginine (A)). Solvent system: n-butanol: acetone: acetic acid: water (35: 35: 10: 20) Detection system: ninhydrin in n-butanol

II. Carbohydrates (Táchira (T), Maracay (M), Boconó (B), Yu-62 (Y)) and control substance (L-proline (P), L-arginine (A)). and control substance (sucrose (S), glucose (G)). Solvent system: 2-propanol: n-butanol: water (12: 3: 4) Detection system: a-naphthol in sulfuric acid.

III and IV. Flavonoids. 1 and 2: Routine; 3: Táchira; 4: Maracay; 5: Boconó; 6: Yu-62; 7: chlorogenic acid; 8: gallic acid. Solvent system: ethyl acetate: formic acid: acetic acid: water (100: 11: 11: 10) Detection system: NP / PE 


\begin{tabular}{|c|c|c|c|c|c|c|c|}
\hline \multirow[b]{2}{*}{ Varieties } & \multicolumn{4}{|c|}{ AMINO ACID } & \multicolumn{3}{|c|}{ PROTEIN } \\
\hline & $\begin{array}{l}\text { Free Proline } \\
\text { Average } \mathrm{mg} / \mathrm{g} \\
\qquad \mathrm{X} \pm \mathrm{S}\end{array}$ & $\mathrm{CV} \%$ & $\begin{array}{c}\text { Average \% } \\
\text { (MS) }\end{array}$ & $\begin{array}{l}\text { Average } \\
\mathrm{mg} / \mathrm{g}(\mathrm{MS})\end{array}$ & $\begin{array}{l}\text { Average Protein } \\
\qquad \begin{array}{c}(\mathrm{mg} / \mathrm{g}) \\
\mathrm{X} \pm \mathrm{S}\end{array}\end{array}$ & $\mathrm{CV} \%$ & $\begin{array}{c}\text { Average } \\
\% \mathrm{MS}\end{array}$ \\
\hline Táchira & $4,50 \pm 0,06 \mathrm{a}$ & 1,38 & $1,60 \mathrm{a}$ & 16,01 & $21,41 \pm 0,06 \mathrm{~b}$ & 3,10 & 7,62 \\
\hline Maracay & $1,96 \pm 0,10 c$ & 4,97 & $0,70 c$ & 6,98 & $23,81 \pm 1,13 \mathrm{a}$ & 4,75 & 8,47 \\
\hline Boconó & $4,39 \pm 0,22 \mathrm{a}$ & 4,98 & $1,56 \mathrm{a}$ & 15,62 & $21,24 \pm 0,83 \mathrm{~b}$ & 3,89 & 7,56 \\
\hline Yu-62 & $3,34 \pm 0,18 b$ & 5,44 & $1,19 \mathrm{~b}$ & 11,89 & $6,86 \pm 0,31 \mathrm{c}$ & 4,56 & 2,44 \\
\hline
\end{tabular}

Legend: There is no data related to the quantification method used. $\mathrm{X} \pm \mathrm{S}=$ mean \pm standard deviation; $\mathrm{CV}$ coefficient of variation.

Different letters indicate significant differences for $\mathrm{P}<0.01$.

Table 1. Concentration of free proline and proteins present in leaves of the varieties of Morus alba $L$.

\begin{tabular}{|c|c|c|c|c|c|c|c|c|c|c|}
\hline & SOLUBLE CA & $\mathrm{OHY}$ & RATES & & & TOTAL & HENC & LS & & \\
\hline Varieties & $\begin{array}{l}\text { Carbohydrates } \\
\qquad \begin{array}{c}(\mathrm{mg} / \mathrm{g}) \\
\mathrm{X} \pm \mathrm{S}\end{array}\end{array}$ & $\begin{array}{l}\mathrm{CV} \\
\%\end{array}$ & $\begin{array}{l}\text { Average } \\
\% \text { (MS) }\end{array}$ & $\begin{array}{c}\text { Soluble } \\
\begin{array}{c}(\mathrm{m} g \mathrm{~g}) \\
\mathrm{X} \pm \mathrm{S}\end{array}\end{array}$ & $\begin{array}{l}\text { CV } \\
\%\end{array}$ & $\begin{array}{l}\text { Linked to the } \\
\text { cell wall }(\mathrm{mg} g) \\
\qquad X \pm S\end{array}$ & $\begin{array}{l}\mathrm{CV} \\
\%\end{array}$ & $\begin{array}{l}\text { Total phenols } \\
\begin{array}{c}(\mathrm{mg} / \mathrm{g}) \\
\mathrm{X} \pm \mathrm{S}\end{array}\end{array}$ & $\begin{array}{l}\mathrm{CV} \\
\%\end{array}$ & $\begin{array}{l}\text { Average } \\
\%(M S)\end{array}$ \\
\hline Táchira & $51.59=1.06^{c}$ & 2.06 & 18.36 & $8.48=0.35^{2}$ & 4.17 & $13.71 \pm 0.60^{6}$ & 4.38 & $22.19 \div 0.49$ & 2.21 & 7.90 \\
\hline Maracay & $68,15 \pm 3,2 \mathrm{~s}^{b}$ & 4,81 & 24,25 & $5,56 \pm 0,28^{b}$ & 4,99 & $8,67 \pm 0,21^{f}$ & 2,38 & $14.23 \pm 0,16$ & 1.12 & 5,06 \\
\hline Boconó & $76.23+3.88^{3}$ & 5.09 & 27.13 & $5.35+0.16^{b}$ & 3.03 & $17.60 \div 0.90^{x}$ & 5.14 & $22.96 \div 0.77$ & 3,36 & 8.17 \\
\hline$Y u-62$ & $68,61=3,0^{b}$ & 4,90 & 24,42 & $5,12 \pm 0,26^{b}$ & 5,02 & $18,89=0,92^{*}$ & 4.89 & $24,01=0,95$ & 3,97 & 8,54 \\
\hline
\end{tabular}

Legend: The content of total phenols was cakculated from the sum of the parameters quantified modvidually for each variety and rephica. $\mathrm{X}=\mathrm{S}=$ mean \pm standard deviation; $\mathrm{CV}$ coefficient of variation. Different letters indicate significant differences for $\mathrm{P}<0.05$ for soluble cartohydrates and $\mathrm{P}-0.01$ for total phenols.

Table 2. Concentration of carbohydrate and phenolic compounds in leaves of the of Morus alba $L$ varieties.

\begin{tabular}{|c|c|c|c|c|}
\hline \multicolumn{2}{|c|}{ Routine quantification by HPTLC } & $\begin{array}{r}\text { IC50 values found for the varieties and for the routine } \\
\text { standard in } \mathbf{p p m}(\mathbf{m g} / \mathbf{L}, \mu \mathrm{g} / \mathbf{m L})\end{array}$ \\
\hline Varieties & $\begin{array}{c}\text { Average Routine } \\
(\mathbf{m g} / \mathbf{g}) \mathbf{X} \pm \mathrm{S}\end{array}$ & $\mathbf{C V} \%$ & Average $\mathbf{I C}_{50}$ \\
\hline Táchira & $0,87 \pm 0,01^{\mathrm{b}}$ & 1,41 & $553,68 \pm 3,23^{\mathrm{d}}$ & 0,58 \\
\hline Maracay & $1,36 \pm 0,06^{\mathrm{a}}$ & 4,06 & $1054,01 \pm 1,76^{\mathrm{c}}$ & 0,17 \\
\hline Boconó & & & $1398,93 \pm 2,23^{\mathrm{b}}$ & 0,16 \\
\hline Yu-62 & & & $3817,89 \pm 18,08^{\mathrm{a}}$ & 0,47 \\
\hline Patrón Rutina & & & $5,25 \pm 0,05$ & 0,90 \\
\hline
\end{tabular}

Legend: $\mathrm{X} \pm \mathrm{S}=$ mean \pm standard deviation; $\mathrm{CV}$ coefficient of variation. Different letters indicate significant differences for $\mathrm{P}<0.01$.

Table 3. Routine concentration and anti-radical activity of the varieties.

could be associated with the presence of gallic acid. In the same way, intense white fluorescence spots were detected for all varieties, one of them with an Rf: 0.45 , which refers to the possible presence of chlorogenic acid. Quercetin could be associated with a yellow stain with an Rf value of 0.74 observed in all the studied varieties, but with a lower intensity in the Boconó and Yu-62 varieties.

\section{Quantification of amino acids (free L-proline) and proteins}

For different varieties of Morus alba cultivated in Cuba, Martin et al.25 have indicated the presence of the 20 essential amino acids and that of them L-proline, valine, arginine and leucine were the most abundant, with quantitative differences between them; but the L-proline values were around $2.13 \%$ DM (dry mass). 
The increase in the concentration of amino acids and L-proline is an indicator to evaluate plants' stress state because, in these conditions, they tend to accumulate free amino acids as a defense mechanism, reducing protein synthesis.

The results achieved the\% (DM) values of L-proline below those obtained for the Cuban varieties (table 1), with the Maracay variety being the lowest value. Regarding the comparison between them, the analysis of variance and the tests of means obtained allowed to observe significant differences of the Táchira and Boconó varieties for Yu-62 and Maracay for $P<0.01$.

Proteins are essential factors for studies related to the nutritional contribution of forage species for animal feed. Plants of the genus Morus have a high protein content (14-28\% on a dry basis $)^{25,31-32}$, making them an exciting alternative in the agricultural area.

In the analyses carried out for the mulberry varieties, low protein values were reached (Table 1), comparable with those found in the Cuban varieties evaluated by Cáceres et $a L^{33}$, which obtained values close to the Maracay, Boconó, and Táchira varieties. According to the variance analysis and the test of means, significant differences could be observed $P<0.01$ between them, the Maracay being the one that presented the highest protein concentration and the Yu-62 the lowest.

Different authors have pointed out the influence of some factors on protein variability in the genus Morus. Some consider that the highest crude protein values depend on the regrowth age and the time of year ${ }^{25}$, while others have outlined the influence of climatic conditions and the use of fertilizers ${ }^{30}$, 32,34-36. In this case, it is considered that when the plants were in the greenhouse, it could have affected the regrowth age and the non-use of fertilizers.

\section{Quantification of soluble carbohydrates and total phenols}

Carbohydrates are the metabolites found in greater quantity in plants, playing an essential role since they provide the necessary energy for the various vital functions in which they participate, mention the formation and growth of tissues, and be associated with recovery plant after pruning. The photosynthetic process mediates the source of soluble carbohydrates in the plant; therefore, environmental factors such as access to water, leaf surface (size of the leaves), and temperature, among other factors, play an essential role ${ }^{37-39}$.

The fact that the studied varieties were in a greenhouse where the incident radiation was necessary, together with a cool environment provided by the non-direct interaction with other plants and a constant watering during the analysis period, allows the studied varieties in the nursery phase they carry out their photosynthetic process efficiently, being evidenced by the size of the leaves despite not observing a great leaf mass.

The variety with the highest concentration of carbohydrates was Boconó, while Táchira had the lowest value (Table 2). The analysis of variance showed significant differences for $P$ $<0.01$ between the varieties.

Generally, as a product of their normal secondary metabolism, all plants can biosynthesize a high number of phenolic compounds, some of which are essential for their physiological functions and others are useful to defend themselves against stressful situations (water, light, ) $)^{10,40}$

In the results obtained (table 2), the highest concentrations of this metabolite belong to the category of phenols linked to the cell wall in which the environmental conditions to which the species are subjected will have a direct impact. Being under the same conditions, the response obtained is characteristic of each variety.
Soluble phenols had the lowest concentrations, which can be associated with defense against pathogenic organisms that directly affect the internal cell system, as shown in some reports in the literature ${ }^{41-43}$.

The variance analysis and the test of means showed highly significant differences $(P<0.01)$ between the varieties for soluble phenols. The highest concentration was obtained in Táchira, while the others behaved statistically similar among them. In the case of phenols bound to the cell wall, there were significant differences between varieties; the Yu-62 and Boconó cultivars presented the highest values and surpassed Táchira and Maracay, a similar behavior to each other.

\section{Routine HPTLC Quantification and Anti-Radical Activity}

According to Polumackanycz ${ }^{10}$, rutin, quercetin, and apigenin are the main bioactive phenolic compounds present in mulberry leaves. Flavanols are the ones that contribute the most to the antioxidant activity in the leaves of the Morus alba species (Flaczyk et $a{ }^{4}{ }^{44}$ ), the most representative compound being rutin (quercitin-3-rutinoside). In the qualitative tests carried out by TLC, rutin could not be visualized in the Boconó and Yu-62 varieties.

The values obtained for Táchira and Maracay are shown in table 3. Significant differences were observed for $P<0.01$ between the two varieties, with Maracay presenting the highest value. The concentrations found were low compared to those published in the bibliography ${ }^{41,44-45}$, although the climatic conditions develop differently from the study object, which influences the results.

Regarding anti-radical activity, the highest $I_{50}$ is the one corresponding to the lowest activity value. It was to be expected that the trend that should be seen in the antioxidant activity would be the same visualized for the content of total phenols; however, the results obtained showed different trends in which the contribution of other metabolites present in some of the varieties could influence, whose synergistic or summative effect contributed to the results found. The analysis of variance showed highly significant differences $(P<0.01)$ between the varieties.

Some authors ${ }^{46,47}$ have reported distinct $I C_{50}$ values for varieties of the genus Morus, but in the comparison between these and the results obtained, the analysis conditions, the type of extract (extraction method and solvent used), the concentration of DPPH used, and reaction time, among many others.

However, the differences between the varieties studied, where the agroecological conditions are the same, are used, maybe due to each variety's intrinsic characteristics.

A joint analysis of the four varieties allowed to establish that the Táchira variety presented the highest content of amino acids (L-proline), soluble phenols, and anti-radical activity; the Macacay variety exhibited the highest protein content and Boconó the highest concentration of carbohydrates, so each of them can be used depending on the objective to be pursued: for animal or therapeutic feeding purposes.

\section{Conclusions}

The analysis of the four varieties allowed to establish that the Táchira variety presented the highest content of amino acids (L-proline), soluble phenols, and anti-radical activity; the Macacay variety exhibited the highest protein content and Boconó the highest concentration of carbohydrates, so each of them can be used depending on the objective to be pursued: for animal or therapeutic feeding purposes. 


\section{Acknowledgment}

To the Institute for Advanced Studies (IDEA). Venezuela; to the Faculty of Sciences. Chemistry School of the Central University of Venezuela and the Escuela Superior Politécnica del Litoral (ESPOL) facilities.

\section{Competing Interests}

Authors have declared that no competing interests exist.

\section{Authors' Contributions}

DSC, MR, and RARS: They contributed the concepts or ideas, design, definition of the intellectual content, data analysis, and revision of the manuscript.

JJQM and YJRA: carried out the bibliographic search, experimental studies, data acquisition, statistical analysis, and manuscript preparation.

MMM: participated in data analysis and editing and final revision of the manuscript.

\section{Bibliographic references}

1. Benavides J. Manejo y utilización de la morera (Morus alba) como forraje. Agrofosteria de las Américas. 1995; 2(7). Obtained from: http://www.fao.org/3/a-x6306s.pdf. Consulted: 9-10-2019

2. Orwa C, Mutua A, Kindt R, Jamnadass R, Simons A. Agrofores tree Database: a tree reference and selection guide version 4.0. 2009. Obtained from: http://www.worldagroforestry.org/treedb2/ AFTPDFS/Morus_alba.pdf Consulted: 9-10-2019.

3. Medina M, García D, Moratinos P, Cova L. La morera (Morus Spp.) como recurso forrajero: avances y consideraciones de investigación. Zootecnia Trop. 2009; 27(4): 343-362.

4. Cholo F y Delgado H. Formación de callos en el cultivo de la morera (Morus alba. L.), Tesis. Universidad de Granma. Facultad de Ciencias Agrícolas. Centro de Estudios de Biotecnología Vegetal. 2011. Obtained from: http://repositorio.utc.edu.ec/bitstream/27000/946/1/T-UTC-1242.pdf Consulted: 9-10-2019.

5. Blanco M, Sierra M. Caracterización bromatológica y evaluación de diferentes niveles de inclusión de morera (Morus alba L.) y sauco (Sambucus nigra L.), en la alimentación de conejos en ceba. Universidad de la Salle. Facultad de zootecnia. Bogota. 2005. 27-29, 34-36. Obtained from: http://repository.lasalle.edu.co/ bitstream/handle/10185/6651/00797701. pdf?sequence=1\&isAllowed=y. Consulted: 9-10-2019.

6. García, Noda Y, Medina M, Martín G, Soca M. Morera: una alternativa viable para los sistemas de alimentación animal en el trópico. Rev. AIA 2006; 10(1) 55-72.

7. Chan EW, Lye PY, Wong SK. Phytochemistry, pharmacology, and clinical trials of Morus alba. Chin J Nat Med. 2016; (1): 17-30. doi: 10.3724 / SP.J.1009.2016.00017.

8. Negro C, Aprile A, De Bellis L, Miceli A. Nutraceutical Properties of Mulberries Grown in Southern Italy (Apulia). Antioxidantes (Basilea). 2019; 8 (7). pii: E223. doi: 10.3390 / antiox8070223.

9. Wu SC, Han F, Song MR, Chen S, Li Q, Zhang Q, Zhu K, Shen JZ. Natural Flavones from Morus alba against Methicillin-Resistant Staphylococcus aureus via Targeting the Proton Motive Force and Membrane Permeability. J Agric Food Chem. 2019; 67(36):1022210234. doi: 10.1021/acs.jafc.9b01795.

10. Polumackanycz M, Sledzinski T, Goyke E, Wesolowski M, Viapiana A. A Comparative Study on the Phenolic Composition and Biological Activities of Morus alba L. Commercial Samples. Moléculas. 2019; 24 (17). pii: E3082. doi: 10.3390 / moléculas24173082.

11. Prausová N, Kollár P. Prenylated phenols with cytotoxic and antiproliferative activity isolated from Morus alba. Ceska Slov Farm. 2019; 68 (2): 48-68.

12. Mahboubi M. Morus alba (mulberry), a natural potent compound in management of obesity. Pharmacol Res. 2019; 146: 104341. doi: $10.1016 /$ j. phrs.2019.104341.
13. Yuan Q, Zhao L. Mulberry (Morus alba L.) Fruit-A Review of Caracteristic Components and Health Benefits. J Agric Food Chem. 2017; 65 (48): 10383-10394. doi: 10.1021 / acs. jafc.7b03614.

14. Jiao Y, Wang X, Jiang X, Kong F, Wang S, Yan C. Antidiabetic effects of Morus alba fruit polysaccharides on high-fat diet- and streptozotocin-induced type 2 diabetes in rats. J Ethnopharmacol. 2017; 199:119-127. doi: 10.1016 / j.jep.2017.02.003.

15. Paudel P, Seong SH, Zhou Y, Ha MT, Min BS, Jung HA, Choi JS. Arylbenzofurans from the Root Bark of Morus alba as Triple Inhibitors of Cholinesterase, $\bigotimes$-Site Amyloid Precursor Protein Cleaving Enzyme 1, and Glycogen Synthase Kinase-3凶: Relevance to Alzheimer's Disease. ACS Omega. 2019;4(4):6283-6294. doi: 10.1021/acsomega.9b00198.

16. Bradford M. A rapid and sensitive method for the cuantitation of microgram quantities of protein utilizing the principle of protein-dye binding. Analytical biochemistry, 1976; 72(1-2): 248-254. doi.org/10.1016/0003-2697(76)90527-3

17. DuBois M, Gilles KA, Hamilton JK, Smith F. Método de Dubois calorimétrico para la determinación de azúcar y sustancias relacionadas. Química analítica 2002; 28 (3): 350-356. doi: 10.1021 / ac60111a017.

18. Teijon, J, Garrido A, Blanco D, Villaverde C, Mendoza C, Ramírez J. Fundamentos de bioquímica estructural. Editorial Tebar. Madrid. España. p 67-69. 2006.

19. Chang C, Yang M, Wen H, Chern J. Estimation of total flavonoid content in propolis by two complementary colorimetric methods. Journal of Food and Drug Analysis. 2002; 10:178-182. ISSN: 1021-9498.

20.Pourmorad F, Hosseinimerhr SJ, Shahabimajd N. Antioxidant activity, phenol and flavonoid contents of some selected Iranian medicinal plants. African Journal of Biotechnology. 2006; 5(11):1142-1145. ISSN 1684-5315

21. Di Rienzo, Casanoves F, Balzarini M, González L, Tablada M, Robledo C. InfoStat versión 2013. Grupo InfoStat, FCA, Universidad Nacional de Córdoba, Argentina. Obtained from: http://www.infostat.com.ar. Consulted: 9-08-2019

22. Soca M, Ojeda F, García DE y Soca M. Efecto del forraje de Morus alba en los indicadores productivos y de salud de bovinos jóvenes en pastoreo. Pastos y Forrajes. 2010, 33 (4):1-10. ISSN 0864-0394.

23. Mora-Valverde D. Usos de la morera (Morus alba) en la alimentación del conejo. el rol de la fibra y la proteína en el Tracto digestivo. Agronomía Mesoamericana 2010, 21(2):357-366. ISSN: 1021-7444

24.Zeng ZJ, lang J, Yu J, Mao X, Yu B, Chen D. Effect of dietary supplementation with mulberry (Morus alba L.) leaves on the growth performance, meat quality and antioxidative capacity of finishing pigs. Journal of Integrative Agriculture 2019, 18(1): 143-151. doi: 10.1016/S2095-3119(18)62072-6.

25. Martín GJ, Noda Y, Pentón G, García DE; García F, González E, Ojeda F, Milera M, López O, Ly J, Leiva L y Arece J. La morera (Morus alba, Linn.): una especie de interés para la alimentación animal. Pastos y Forrajes 2007, 30(5) ISSN 0864-0394.

26. Xirui $H$, Jiacheng F, Yinlan R, Xiaoxiao W, Yin S, Ni W, Zefeng Z, Yu Ch, Ning N, Hao G, Linhong H. Structures, bioactivities and future prospective of polysaccharides from Morus alba (white mulberry): A review. Food Chemistry 2018, 245:899-910

27. Yang $Y$, Zhang T, Xiao L, Yang L, Chen R. Two new chalcones from leaves of Morus alba L. Fitoterapia 2010, 81(6):614-616. doi: 10.1016/j.fitote.2010.03.005

28. Huang QH, Lei Ch, Wang PP, Li JY, Li J, Ho AJ. Isoprenylated phenolic compounds with PTP1B inhibition from Morus alba. Fitoterapia. 2017, 122:138-143. doi: 10.1016/j.fitote.2017.09.006.

29. Zhang H, Li M, Wang MM, Wang XN, Shen T, Wang SQ, Ren DM. Antioxidant flavan derivatives from the leaves of Morus alba. Phytochemistry Letters. 2019, 29: 84-90. doi: 10.1016/j.phytol.2018.11.002.

30.Pesqueira J. Cambios bioquímicos, morfológicos y ecofisiológicos en plantas del género Lotus bajo estrés salino. Tesis doctoral. Universidad Politécnica de Valencia. Departamento de Biología Vegetal. 2008. Obtained from: https://riunet.upv.es/bitstream/ handle/10251/5765/tesisUPV3030.pdf. Consulted: 10-09-2019 
31. Benavides J. Utilización de la Morera en sistemas de producción animal. Conferencia electrónica de la FAO sobre "Agroforestería para la producción animal en Latinoamérica". Obtained from http://www.fao.org/ag/aga/agap/frg/agrof orl/Bnvdes12.htm. Consulted: 11-10-2019

32. Noda, Y, Martín, G.; Machado, R. Rendimiento y calidad bromatológica de Morus alba cosechada a diferentes alturas y frecuencias de defoliación. Revista Cubana de Ciencia Agrícola. 2007; 41(4):363-369. ISSN: 0034-7485.

33. Cáceres $\mathrm{O}$, González E. Valor nutritivo de árboles, arbustos y otras plantas forrajeras para los rumiantes. Pastos y Forrajes 2002, 25:15-20. ffhal-01190060f

34. Boschini FC, Dormond H., Castro H, Composición química de la morera (Morus alba), para uso en la alimentación animal: densidades y frecuencias de poda. Agronomía Mesoamericana. 2000, 11(1):41-49. ISSN: 1021-7444 pccmca@cariari.ucr.ac.cr

35. Hurtado DI, Nocua S, Narváez-Solarte W, Vargas-Sánchez JE. Valor nutricional de la morera (Morus sp.), matarratón (Gliricidia sepium), pasto indio (Panicum máximum) y arboloco (Montanoa quadrangularis) en la alimentación de cuyes (Cavia porcellus) vet. Zootec 2012, 6(1): 56-65.

36. García Soldevilla F y Fernández R. Influencia de la frecuencia de poda y la época sobre los rendimientos de biomasa de la morera (Morus alba). Revista Computadorizada de Producción Porcina 2004, 11(1):64-74.

37. Yepes A; Silveira Buckeridge M. Respuestas de las plantas ante los factores ambientales del cambio climático global (Revisión) Colombia Forestal 2011, 14(2):213-232. ISSN: 0120-0739

38.Pérez-Urria E. Fotosíntesis: Aspectos Básicos. Reduca (Biología). Serie Fisiología Vegetal. 2009, 2 (3): 1-47. ISSN: 1989-3620

39. Azcón-Bieto J, Fleck I, Aranda X Y Gómez-Casanovasuria N. Fotosintesis, factores ambientales y cambio climático. 2013. Obtained from: http://biblio3.url.edu.gt/Publi/Libros/2013/FisioVegetal/13. pdf. Consulted: 11-10-2019.

40.Chen XY., Zhang T., Wang X., Hamann T., Kang J., Yu DQ., Chen RY. A chemical investigation of the leaves of Morus alba L. Molecules. 2018; 23:1018. doi: 10.3390 / molecules23051018.

41. Radojkovic M, Zekovic Z, Vidovic S, Kocar D, Mascovic P. Free radical scavenging activity and total phenolic and flavonoid contents of mulberry (Morus spp. L., Moraceae) extracts. Hem. Ind. 2012 $66(4): 547-552$

42. Memon A, Memon M, Luthria D, Bhanger M, Pitafi A. Phenolic acid profiling and antioxidant potential of mulberry (Morus laevigata W., Morus nigra L., Morus alba L.) leaves and fruits grown in Pakistan, Pol. J. Food. Nutr. Sci. 2010, 60(1):2532.

43.García D, Ojeda F. Evaluación de los principales factores que influyen en la composición fitoquímica de Morus alba (Linn.) II. Polifenoles totales. Pastos y forrajes. 2004, 27(1): 59-64.
44.Flaczyk E, Kobus-Cisowska J, Przeor M, Korczak J, Remiszewsk $M$, Korbas E, Buchowski M. Chemical characterization and antioxidative properties of Polish variety of Morus alba L. leaf aqueous extracts from the laboratory and pilot-scale processes. Agricultural Sciences 2013, 4(5B):141-147 doi:10.4236/as.2013.45B026

45. Yu WT, Kwon OC, Kim HB, Sung GB, Kim HW, Kim YS Qualitative and quantitative analysis of flavonoids from 12 species of Korean mulberry leaves. Qualitative and quantitative analysis of flavonoids from 12 species of Korean mulberry leaves. J. Food Sci. Technol. 2018; 55:1789-1796. doi: 10.1007 / s13197-018-3093-2.

46. Ali MK, Abdu AR, Islam S, Khandokhar P, Parvin S, Badrul MI, et al., A comparative study on the antioxidant activity of methanolic extracts from different parts of Morus alba L. (Moraceae) BMC Res Notes. 2013; 6:24. doi: 10.1186 / 1756-0500-6-24

47. Farahani M, Salehi-Arjmand H, Khadivi A, Akramian M. Chemical characterization and antioxidant activities of Morus alba var. nigra fruits. Scientia Horticulturae. 2019. 253:120-127. doi: 10.1016/j. scienta.2019.04.040.

Received: 20 noviembre 2020

Accepted: 20 enero 2021 